F. Reprod. Fert. (1972) 30, 395-405

\title{
THE GROWTH IN VITRO OF MOUSE OVARIAN FOLLICLES OF DIFFERENT SIZES IN RESPONSE TO PURIFIED GONADOTROPHINS
}

\author{
MARGARET RYLE \\ United Birmingham Hospitals Department of Clinical Endocrinology, \\ Birmingham and Midland Hospital for Women, Birmingham B11 4HL
}

(Received 19th Fuly 1971, accepted 4th October 1971)

\begin{abstract}
Summary. Ovaries of infantile mice were cultured in vitro with no hormone, LH or FSH for 2 or 5 days, $\left[{ }^{3} \mathrm{H}\right]$ thymidine being present in the medium for the last $24 \mathrm{hr}$ of culture. Each ovary was serially sectioned and autoradiographs were prepared. The effects of the treatments on follicle numbers and on the extent to which they were labelled were examined in groups of follicles of different sizes. Growth was stimulated by FSH in follicles of all sizes both on Day 2 and Day 5, but LH did not stimulate growth in primordial follicles and had relatively little effect on one- and two-cell layer follicles. It greatly accelerated growth in some with three- and four-cell layers on Day 5, but not on Day 2. It also appeared to stimulate mitosis in the theca interna whereas FSH appeared to diminish it. A few follicles grew rapidly on Day 5 in the absence of any hormone. Spindle formation in oocytes was associated with rapid follicle growth but not with hormone treatment. Possible explanations of the delayed effect of $\mathbf{L H}$ are discussed.
\end{abstract}

\section{INTRODUGTION}

The distributions of follicle diameters in infantile mouse ovaries, after culture in vitro with human pituitary gonadotrophins, suggest that all sizes grow more rapidly and constantly when FSH is present in the medium. By contrast, LH seems to stimulate growth only after Day 3 of culture (Ryle, 1971a). The experiment described below was designed to identify more precisely those follicles growing actively on Day 2 and Day 5 of culture and to compare follicle growth rates in the absence of gonadotrophin with those occurring in the presence of either FSH Or LH.

\section{MATERIALS AND METHODS}

The hormones and the culture procedure were as described previously (Ryle, 1971a) except for the following details. The FSH preparation (Butt, Lynch \& Kennedy, 1972), present at a concentration of $0.5 \mathrm{i} . \mathrm{u} . / \mathrm{ml}$, was more highly purified than that used in the previous experiment. The LH preparation was 
used at 1.0 i.u./ml. As before, the hormones were put in the medium before the tissue was explanted. Under similar conditions, a comparable preparation of FSH retained full activity for more than a week (Ryle, 1971b). It is not known whether LH is equally stable. Each $100-\mathrm{ml}$ medium was supplemented with an extra $2 \mathrm{ml} 200 \mathrm{~mm}$-glutamine just before use. The dishes were cooled before the tissue was explanted and were kept at room temperature for $2 \mathrm{hr}$ afterwards, since this delay markedly reduced pycnosis in the centre of similar cultured ovaries.

The ovaries were obtained from nine 15-day-old CFW mice, weighing $7 \cdot 0$ to $7.5 \mathrm{~g}$, that had been reared as a single foster litter. The ovaries of such fosterlitter mates usually respond to gonadotrophins more uniformly, when cultured in vitro, than do those of mice reared by different females. Three mice were allocated to the control group, three to the LH group and three to the FSH group. The two ovaries of each mouse were cultured separately in a pair of dishes. Cells which contained DNA synthesized during Day 2 and Day 5 of culture, and which were presumably undergoing mitosis at these times, were identified as follows. Twenty-four hours after explantation, $1 \mu \mathrm{Ci}$ [methyl- $\left.{ }^{3} \mathrm{H}\right]$ thymidine $(18.3$ $\mathrm{Ci} / \mathrm{mm}$; the Radiochemical Centre, Amersham) in $0.1 \mathrm{ml}$ medium was added to one of each pair of culture dishes. Twenty-four hours later, these ovaries were put into Bouin's aqueous fixative. Four days after explantation, [methyl$\left.{ }^{3} \mathrm{H}\right]$ thymidine was similarly added to the parallel set of cultures. The ovaries were again fixed $24 \mathrm{hr}$ later. There were, thus, two groups of ovaries which received no hormone: those exposed to $\left[{ }^{3} \mathrm{H}\right]$ thymidine on Day 2 and those exposed on Day 5. Two similar groups were treated with LH and two more with FSH. In each of these six treatment groups, there were three ovaries.

Serial sections $(5 \mu \mathrm{m})$ were cut from each ovary and autoradiographs were prepared, using Ilford K2 Nuclear Research Emulsion. The sections were stained with Harris's haematoxylin before mounting. The slides were then allocated random code numbers and examined 'blind' under dark-ground illumination to assess the extent of nuclear labelling. Data were obtained for all ovaries in three ways. (1) Every section was inspected and each follicle that was cut in the plane of its oocyte nucleolus and had three or more layers of granulosa cells was individually recorded. The number of granulosa-cell layers was noted and the proportion of heavily labelled granulosa-cell nuclei was estimated $(<25 \%, 25$ to $50 \%, 50$ to $75 \%,>75 \%$ ). No absolute measurement of labelling of individual nuclei was attempted since the intensity tended to be much greater in peripheral than in central regions. This was probably due to slow diffusion inwards of the thymidine. The degree of pycnosis of each of these follicles was recorded on a scale of 1 (very slight) to 6 (severe). (2) In the first and every following fifth section, follicles were recorded which contained enlarged oocytes cut in the plane of the nucleus but which had only one or two layers of granulosa cells. The number of layers and the number of heavily labelled granulosa-cell nuclei in that section were noted for each such follicle. Partially or wholly pycnotic follicles were included providing that the oocyte nucleus was identifiable. (3) No quantitative data were recorded for other tissue components but each set of serial sections was carefully inspected, special attention being paid to thecal cells, to primordial follicles and to stromal cells 

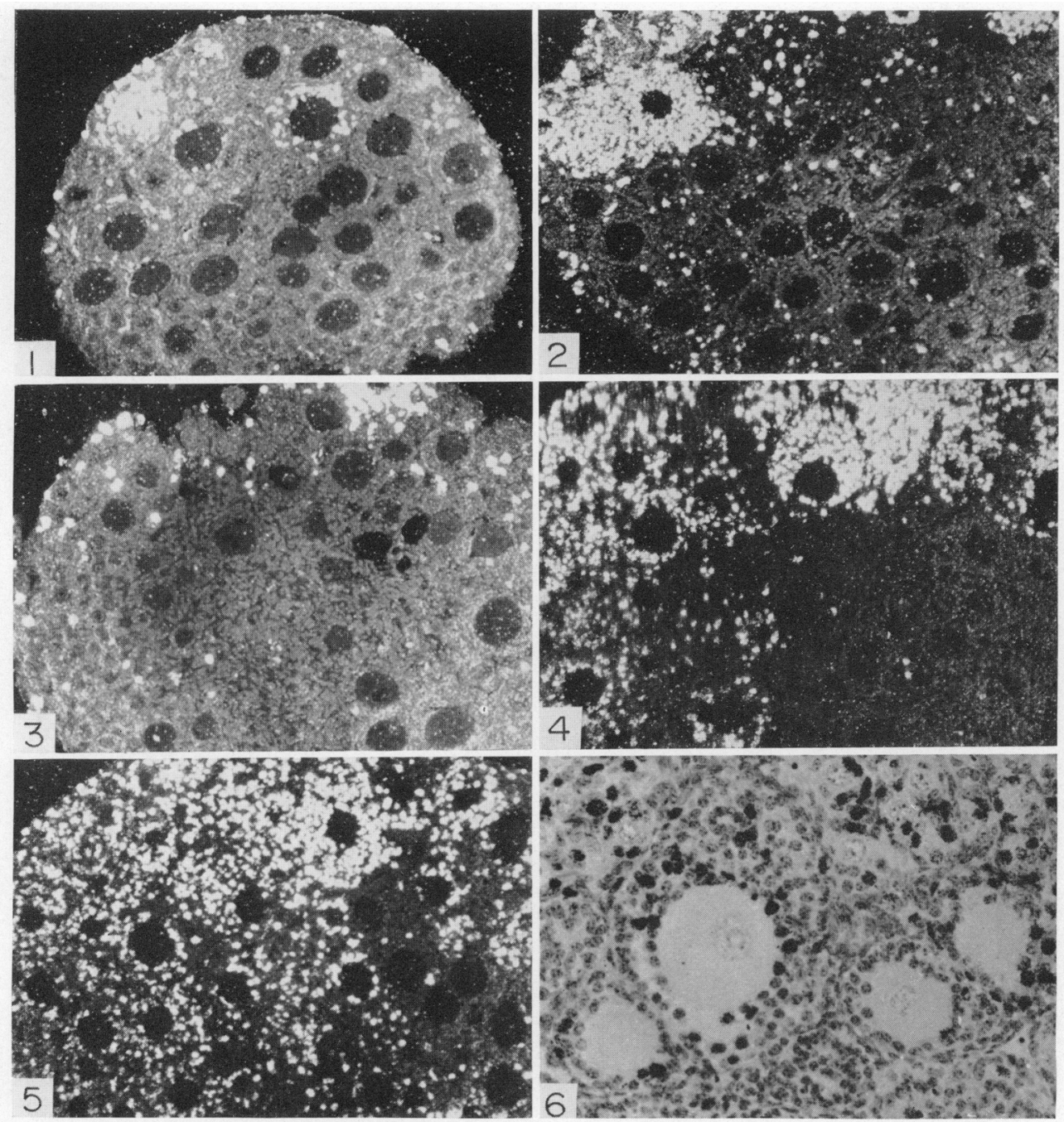

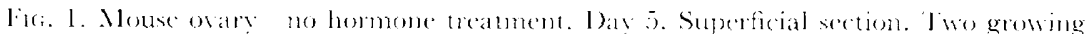

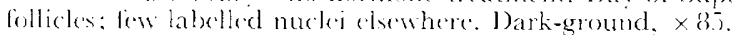

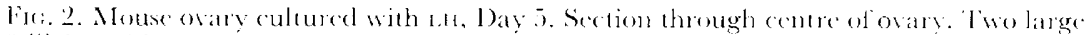

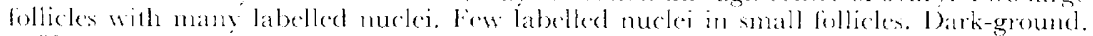
$\times 8$.

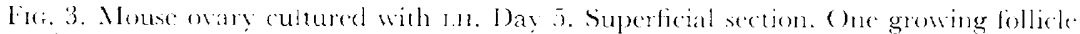
litule label in area of prinordial follicles. Dark-ground. $\times 38$.

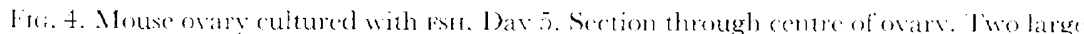

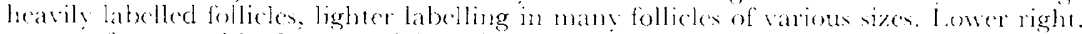
centre of owary whth almos no labelled nuclei. I)atk-ground, $x 85$.

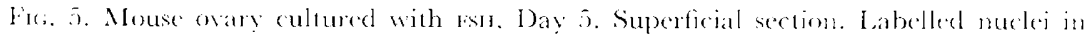
follicles of all sizes, including primordials. Dark-ground. $\times 8.7$.

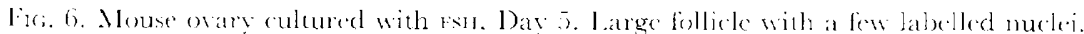

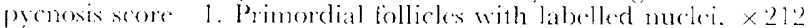




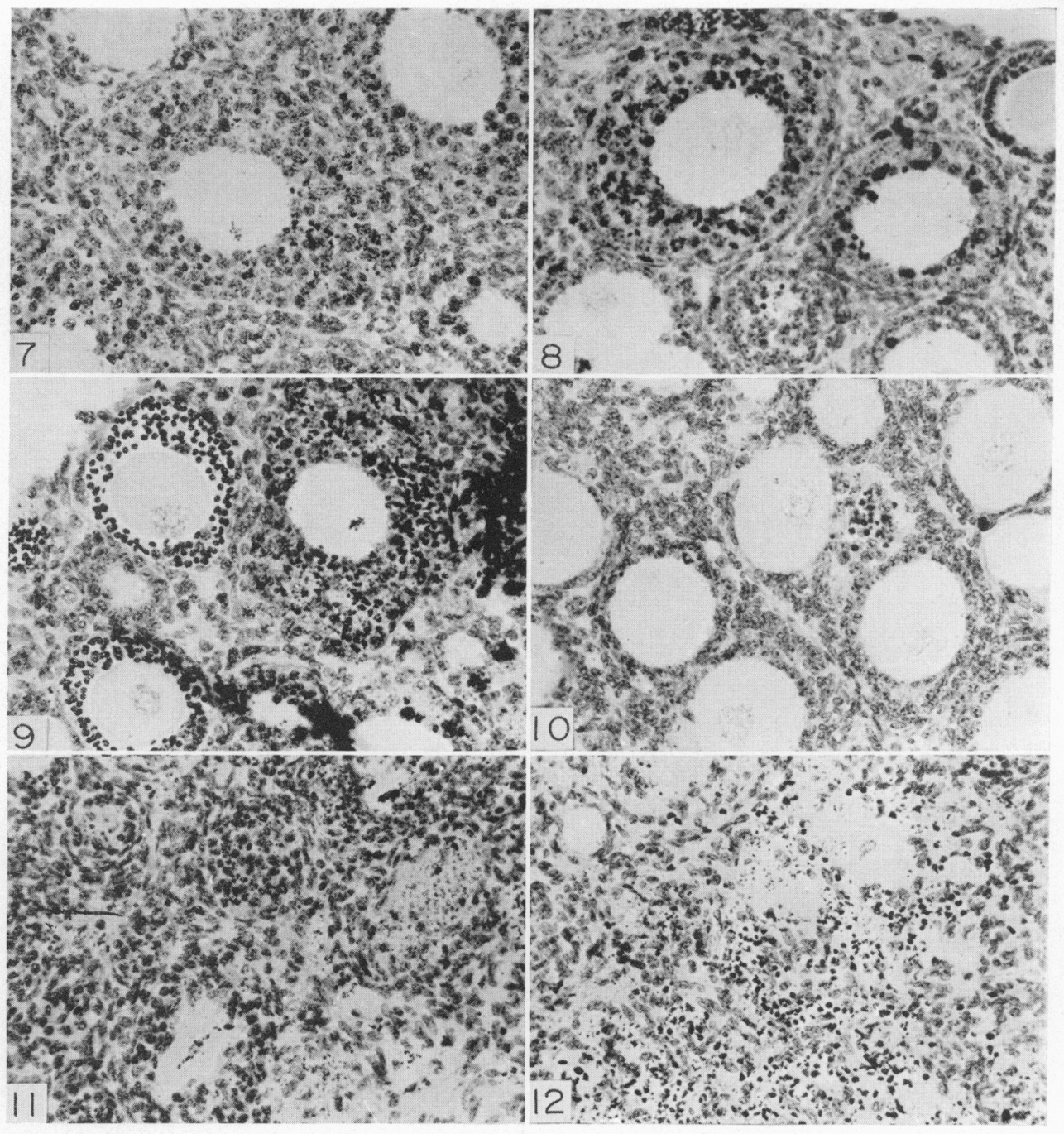

lir. 7. Mouse ovary cultured with Fsi, Day 5 . Large follicle, labelling of nuclei not intense because not near periphery of ovary and therefore not distinct by transmitted light; poorly defined theca; oocyte spindle; pycnosis score $-2 . \times 212$.

lite. 8. Mouse ovary cultured with L.H, Day 5. Heavily labelled three-cell-layer follicle; well defined theca with some labelled nuclei; pycnosis score-. 3 . Two-cell-layered follicle with labelled nuclei in inner layer only, $\times 212$.

lis;. 9. Mouse ovary cultured with Li, Day 5. Large, heavily labelled follicle; oocyte spindle; pycnosis score- 4. Two small follicles; pycnosis score-6, with condensed nuclei characteristic of ovaries cultured without FSH. $\times 212$.

Fig. 10. Mouse ovary cultured with LH. Day 5. Enlarged oocytes surrounded by only one or two laycrs of granulosa cells, characteristic of ovaries cultured without $\mathrm{rsH} . \times 212$.

FIG. 11. Mouse ovary cultured with FsH, Day 5. Right: central region of ovary; follicles with degencrating granulosa. I,eft: follicles in which oocytes are degenerating or have disappeared but in which many healthy granulosa cells remain; characteristic of ovarics cultured with FsII. $\times 212$.

Fig 12. Mouse ovary cultured with FsH, Day 5. Damaged tissue typical of centre of ovary cultured for 5 days with Fsi. $\times 212$. 
between primordial follicles. Notes were also made on the extent and types of pycnosis and on the presence of spindles in oocytes.

A few sections were lost from four ovaries, one each from the LH-treated groups labelled on Day 2 and Day 5 and one each from the FsH-treated groups on Day 2 and Day 5. In neither case were paired ovaries affected. Any consequent slight underestimates of follicle numbers have been ignored.

\section{RESULTS}

Plate 1, Figs 1 to 5 show the labelled nuclei in sections of ovaries cultured for 5 days with no hormone, LH or FSH. The results of detailed and quantitative examination of the serial sections are described below.

\section{The theca interna}

Thecal cells with labelled nuclei were observed at the periphery of a proportion of follicles in all size categories with more than two layers of granulosa cells (P1. 2, Fig. 8). This proportion appeared to vary considerably between ovaries within each treatment, as did the ratio of labelled to unlabelled thecal cells surrounding follicles of a given size. In general, large follicles with a high proportion of labelled granulosa-cell nuclei had relatively few labelled theca-cell nuclei. No differences due to the hormone treatments were obvious on Day 2 but, on Day 5, thecal labelling appeared to be least in the presence of FSH and greatest in the presence of LH. Moreover, in ovaries cultured with FSH, the thecal cells were flat and sparse so that the boundaries of the larger follicles were often poorly defined (Pl. 2, Fig. 7).

\section{Primordial follicles and associated stromal cells}

On Day 2, few of the primordial follicle-cell nuclei took up $\left[{ }^{3} \mathrm{H}\right]$ thymidine in the absence of FSH. On Day 5, almost none did. Treatment with FSH resulted in labelled nuclei in a moderate proportion of primordial follicles both on Day 2 and on Day 5 (Pl. 1, Fig. 6). With no gonadotrophin, few of the stromal cells between these follicles acquired label on Day 2 and almost none on Day 5 . Treatment with LH appeared to increase the frequency of labelled stromal cells slightly on both days. On Day 2, FSH tended to have a somewhat more marked effect but, by Day 5 , its effect was similar to that of $\mathrm{LH}$.

\section{Follicles with enlarged oocytes and one layer of granulosa cells}

Table 1, Column i, summarizes the effects of FSH and LH on the mean number of one-cell-layered follicles per ovary. Column ii shows the mean proportion of those follicles in which labelled granulosa-cell nuclei were observed, indicating growth during the labelling period. The other two columns are concerned with the rate of this growth: (iii) the median number of labelled nuclei per follicle for the population of growing follicles in each ovary and (iv) the mean number of labelled nuclei in the three most heavily labelled follicles of each ovary, i.e. in those growing most rapidly. Student's $t$ test was used to estimate the significance of the differences between relevant treatment means in these and subsequent results. The modification for sets of paired data was used throughout to compare 
the effect of a given hormone treatment on Day 2 and Day 5, for which paired ovaries were employed.

Both hormones reduced the number of follicles with enlarged oocytes and a single layer of granulosa cells. By Day 2, LH already had a significant effect. The

\section{TABLE 1}

MOUSE FOLLICLES WITH ENLARGED OOCYTES AND ONE LAYER OF GRANULOSA CELLS

\begin{tabular}{|c|c|c|c|c|c|c|c|c|}
\hline & \multicolumn{2}{|c|}{$\begin{array}{l}\text { No. of follicles } \\
\text { lovary }\end{array}$} & \multicolumn{2}{|c|}{$\begin{array}{l}\% \text { follicles with } \\
\text { labelled nuclei }\end{array}$} & \multicolumn{2}{|c|}{$\begin{array}{l}\text { Median no. of } \\
\text { labelled nuclei in } \\
\text { labelled follicles }\end{array}$} & \multicolumn{2}{|c|}{$\begin{array}{l}\text { Mean no. of labelled } \\
\text { nuclei in three most } \\
\text { heavily labelled } \\
\text { follicles }\end{array}$} \\
\hline & Day 2 & Day 5 & Day 2 & Day 5 & Day 2 & Day 5 & Day 2 & Day 5 \\
\hline LH & $\begin{array}{r}75 \cdot 3 \\
\pm 5 \cdot 2 \\
*\end{array}$ & $\begin{array}{r}75 \cdot 3 \\
\pm 22 \cdot 8\end{array}$ & $\begin{array}{r}88 \cdot 3 \\
\pm 2 \cdot 3\end{array}$ & ** $\begin{array}{r}39.5 \\
\\
\pm 7.0\end{array}$ & $\begin{array}{r}3.00 \\
\pm 0.00\end{array}$ & $\begin{array}{r}2.67 \\
\pm 0.33\end{array}$ & $\begin{array}{r}8 \cdot 8 \\
\pm 0.5 \\
*\end{array}$ & $\begin{array}{r}9 \cdot 4 \\
\pm 2 \cdot 2\end{array}$ \\
\hline Control & $\begin{array}{r}109.0 \\
\pm 10.5\end{array}$ & $\begin{array}{c}115 \cdot 0 \\
\pm 6 \cdot 1 \\
* *\end{array}$ & $\begin{array}{r}81 \cdot 2 \\
\pm 2.9\end{array}$ & $\begin{array}{c}* 36 \cdot 8 \\
\pm 6 \cdot 1 \\
* * *\end{array}$ & $\begin{array}{r}2.00 \\
\pm 0.00 \\
*\end{array}$ & $\begin{aligned} & 1.67 \\
& \pm 0.33 \\
& * * *\end{aligned}$ & $\begin{array}{r}7 \cdot 1 \\
\pm 0 \cdot 1 \\
* * *\end{array}$ & $\begin{array}{r}11.2 \\
\pm 1.5\end{array}$ \\
\hline FSH & $\begin{array}{r}92 \cdot 7 \\
\pm 14.5\end{array}$ & $\begin{array}{r}58 \cdot 0 \\
\pm 13.5\end{array}$ & $\begin{array}{r}88 \cdot 6 \\
\pm 3 \cdot 2\end{array}$ & $\begin{array}{r}85 \cdot 0 \\
\pm 4.3\end{array}$ & $\begin{array}{r}4.00 \\
\pm 0.58\end{array}$ & $\begin{array}{r}5.00 \\
\pm 0.58\end{array}$ & $\begin{array}{r}13.7 \\
\pm 1.0\end{array}$ & $\begin{array}{r}12.7 \\
\pm 1.0\end{array}$ \\
\hline
\end{tabular}

Values expressed as Means \pm S.E.M. Significance of differences between vertically and horizontally adjacent treatment means in this and the following tables: ${ }^{*} P=0.05, * * P=$ $0.02, * * * P=0.01, * * * P=0.001$.

TABLE 2

MOUSE FOLLICLES WITH TWO LAYERS OF GRANULOSA GELLS

\begin{tabular}{|c|c|c|c|c|c|c|c|c|c|}
\hline & \multicolumn{2}{|c|}{$\begin{array}{l}\text { No. of follicles } \\
\text { lovary }\end{array}$} & \multicolumn{3}{|c|}{$\begin{array}{l}\% \text { follicles with } \\
\text { label }\end{array}$} & \multicolumn{2}{|c|}{$\begin{array}{l}\text { Median no. of } \\
\text { labelled nuclei in } \\
\text { labelled follicles }\end{array}$} & \multicolumn{2}{|c|}{$\begin{array}{l}\text { Mean no. of labelled } \\
\text { nuclei in three most } \\
\text { heavily labelled } \\
\text { follicles }\end{array}$} \\
\hline & Day 2 & Day 5 & Day 2 & & Day 5 & Day 2 & Day 5 & Day 2 & Day 5 \\
\hline LH & $\begin{array}{r}70.7 \\
\pm 3.2\end{array}$ & $\begin{array}{r}45.0 \\
\pm 13.0\end{array}$ & $\begin{array}{r}81 \cdot 3 \\
\pm 3 \cdot 2\end{array}$ & & $\begin{array}{r}44.7 \\
\pm 7.4\end{array}$ & $\begin{array}{r}3.33 \\
\pm 0.33\end{array}$ & $\begin{array}{r}3.33 \\
\pm 1.45\end{array}$ & $\begin{array}{r}9.8 \\
\pm 0.8\end{array}$ & $\begin{array}{r}12.9 \\
\pm 4.4\end{array}$ \\
\hline Control & $\begin{array}{r}80.0 \\
\pm 13.5\end{array}$ & $\begin{array}{r}59 \cdot 7 \\
\pm 9 \cdot 7\end{array}$ & $\begin{array}{r}83 \cdot 6 \\
\pm 4 \cdot 1\end{array}$ & $* * *$ & $\begin{array}{r}38 \cdot 6 \\
\pm 2 \cdot 4 \\
* * * *\end{array}$ & $\begin{array}{r}2.67 \\
\pm 0.33 \\
* *\end{array}$ & $\begin{array}{r}1.67 \\
\pm 0.33 \\
* * * *\end{array}$ & $\begin{array}{r}8 \cdot 6 \\
\pm 0.4 \\
+* *\end{array}$ & $\begin{array}{r}9 \cdot 4 \\
\pm 2 \cdot 5 \\
* * *\end{array}$ \\
\hline FSH & $\begin{array}{r}58 \cdot 0 \\
\pm 3 \cdot 6\end{array}$ & $\begin{array}{r}46 \cdot 3 \\
\pm 11 \cdot 3\end{array}$ & $\begin{array}{r}93 \cdot 9 \\
\pm 2 \cdot 3\end{array}$ & * & $\begin{array}{r}82 \cdot 7 \\
\pm 2 \cdot 7\end{array}$ & $\begin{array}{r}9.00 \\
\pm 1.53\end{array}$ & $\begin{array}{r}10.33 \\
\pm 0.88\end{array}$ & $\begin{array}{r}28 \cdot 5 \\
\pm 2 \cdot 4\end{array}$ & $\begin{array}{r}23 \cdot 8 \\
\pm 1 \cdot 3\end{array}$ \\
\hline
\end{tabular}

Values expressed as Means \pm S.E.M.

percentage of growing follicles was similar for all treatments on Day 2 but, by Day 5, it had declined sharply in the absence of FsH. Moreover, as Column iii shows, FSH was stimulating more rapid growth as early as Day 2 and this effect was still more marked by Day 5 . When only the three most actively growing follicles are considered, a marked effect of FSH and also a small increase due to 
LH are indicated on Day 2 but, by Day 5, a few follicles were also growing quite rapidly in the control ovaries.

\section{Follicles with two layers of granulosa cells}

Although the mean number of two-cell-layer follicles/ovary appeared to be slightly reduced by both hormones and declined between Day 2 and Day 5 , none of the differences was significant (Table 2, Column i). The mean percentage of follicles with labelled nuclei, (Column ii) - like that of the one-celllayered follicles-declined between Day 2 and Day 5 in the absence of FsH. The median number of labelled nuclei/growing follicle (Column iii) was again substantially increased by FSH both on Day 2 and on Day 5 . The growth rate of the most rapidly growing follicles (Column iv) was not significantly affected by LH but FSH very markedly increased it both on Day 2 and on Day 5.

\section{TABLE 3}

NUMBERS OF FOLLIGLES PER MOUSE OVARY WITH THREE, FOUR AND FIVE OR MORE LAYERS OF GRANULOSA GELLS

\begin{tabular}{|c|c|c|c|c|c|c|}
\hline & \multicolumn{2}{|c|}{$\begin{array}{l}\text { No. of follicles with } \\
\text { three layers }\end{array}$} & \multicolumn{2}{|c|}{$\begin{array}{l}\text { No. of follicles with } \\
\text { four layers }\end{array}$} & \multicolumn{2}{|c|}{$\begin{array}{l}\text { No. of follicles with } \\
\text { five or more layers }\end{array}$} \\
\hline & Day 2 & Day 5 & Day 2 & Day 5 & Day 2 & Day 5 \\
\hline LH & $\begin{array}{r}23 \cdot 0 \\
\pm 3 \cdot 8\end{array}$ & $\begin{array}{r}12 \cdot 0 \\
\pm 3 \cdot 5\end{array}$ & $\begin{array}{r}0.3 \\
\pm 0 \cdot 3\end{array}$ & $\begin{array}{r}3 \cdot 7 \\
\pm 2 \cdot 2\end{array}$ & 0.0 & $\begin{array}{r}2 \cdot 0 \\
\pm 1 \cdot 0\end{array}$ \\
\hline Control & $\begin{array}{c}14.3 \\
\pm 2.9 \\
* *\end{array}$ & $\begin{array}{r}9 \cdot 0 \\
\pm 2 \cdot 6 \\
* * *\end{array}$ & $\begin{array}{r}0.7 \\
\pm 0.3 \\
* *\end{array}$ & $\begin{array}{r}0.7 \\
\pm 0.7 \\
* * *\end{array}$ & $0 \cdot 0$ & $\begin{array}{r}1 \cdot 0 \\
\pm 1 \cdot 0\end{array}$ \\
\hline FSH & $\begin{array}{r}45 \cdot 3 \\
\pm 6 \cdot 8\end{array}$ & $\begin{array}{r}42 \cdot 0 \\
\pm 4 \cdot 0\end{array}$ & $\begin{array}{r}18 \cdot 7 \\
\pm 4 \cdot 7\end{array}$ & $\begin{array}{r}24 \cdot 0 \\
\pm 3 \cdot 2\end{array}$ & $\begin{array}{r}1.3 \\
\pm 0.7\end{array}$ & $\begin{array}{r}10 \cdot 3 \\
\pm 6 \cdot 1\end{array}$ \\
\hline
\end{tabular}

Values expressed as Means \pm S.E.M.

Follicles with three, four and five or more layers of granulosa cells

The mean numbers of three- and four-cell-layer follicles/ovary were significantly increased by FSH, both on Day 2 and on Day 5 (Table 3, Columns i and ii). There were no follicles with five or more layers of granulosa cells on Day 2 unless FSH was present (Column iii). On Day 5, the number in this category varied widely in the ovaries treated with FSH and their mean was not significantly greater than the control value. The numbers of follicles with three, four and five or more layers were generally higher in the LH-treated ovaries than in the controls but variations between similarly treated ovaries were considerable and there were no significant LH effects.

Since there were few follicles in the larger size categories, data from the three ovaries in each treatment group have been pooled and totals instead of means are presented in Text-fig. 1 to illustrate the effects of treatment on the labelling of these follicles. The numbers of follicles with three, four and five or more layers of granulosa cells that were present on Day 2 and on Day 5 are shown for each hormone treatment. After 5 days' culture, the distribution ratios between the three classes were approximately $9: 1: 1$ for the control ovaries, $6: 2: 1$ for the 
LH-treated ovaries and 4:2:1 for the FsH-treated ovaries. The significance of the differences between the ratios was tested, using the $\chi^{2}$ test. Only FsH significantly altered the follicle size distribution relative to the controls $(P<0 \cdot 005)$.

Almost no follicles in these size categories were totally devoid of labelled nuclei. In the more slowly growing ones, labelled nuclei were concentrated in the innermost layer of the granulosa. As the histograms show, the intensity of

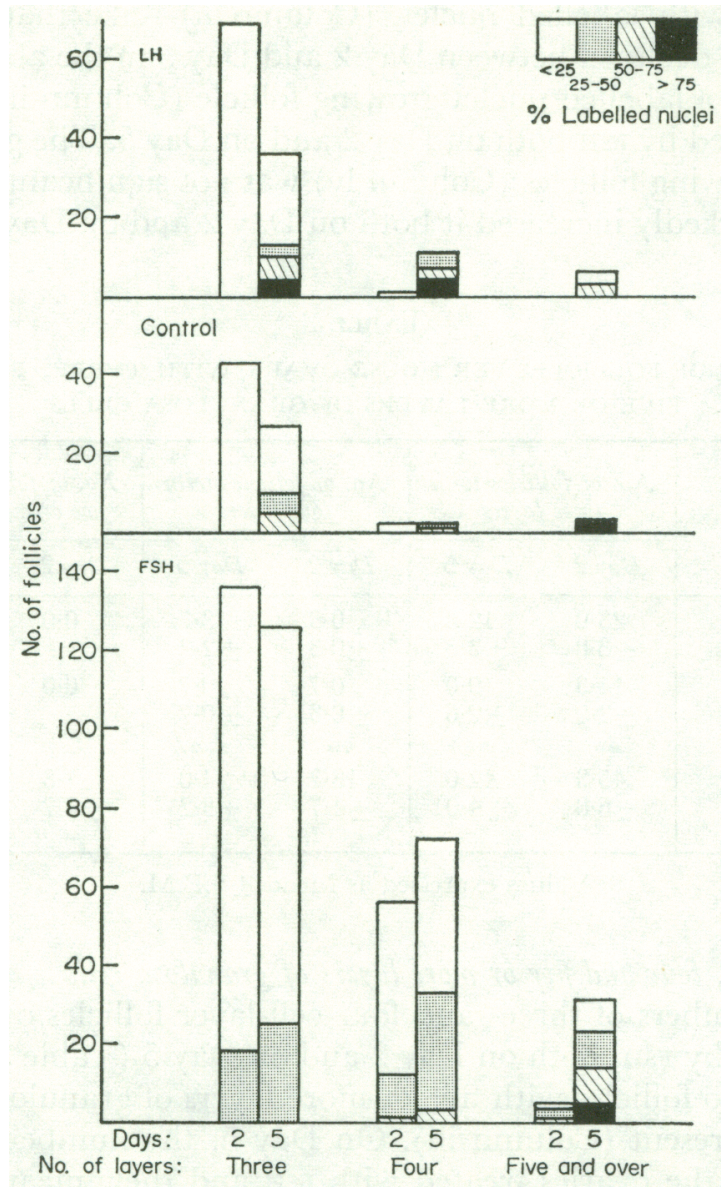

TEXT-FIG. 1. Numbers of follicles with three, four and five or more layers of granulosa cells after culture for 2 and for 5 days in the presence of LH, no hormone and PSH. Each group is the total for three ovaries and is sub-divided according to the percentage of labelled granulosa-cell nuclei.

labelling varied with treatment. The significance of differences between ratios of heavily: lightly labelled follicles has been estimated for pooled data derived from Text-fig. 1 , by calculating $\chi^{2}$ for a series of $2 \times 2$ contingency tables. On Day 2, very few follicles of any size had more than $50 \%$ labelled nuclei. On Day 5, however, substantial differences associated with hormone treatments were apparent. Considering the three- and four-cell-layer follicles together, only $1.5 \%$ in FsH-treated ovaries had more than half their nuclei labelled com- 
pared to $20.7 \%$ in the controls $(P<0.01)$. In the LH-treated ovaries, $36.2 \%$ had more than half of their nuclei labelled while, in $17 \%$, over three-quarters were labelled. No follicles of this size had $75 \%$ of their nuclei labelled in either the control or the FsH-treated ovaries $(P<0.02$, LH versus control). In the absence of $\mathrm{LH}$, such active growth was seen in only a few follicles with five or more layers of granulosa cells.

Within a proportion of the rapidly growing follicles ( $>50 \%$ labelled nuclei), the membrane of the oocyte nucleus had disappeared and spindle formation had occurred (Pl. 2, Figs 7 and 9). This phenomenon was not seen in the oocytes of smaller follicles nor, with a single exception, within follicles of equal or greater size which were growing less rapidly. It was not related to the presence or absence of either gonadotrophin but seemed to be associated simply with rapid granulosa-cell proliferation.

\section{The condition of the tissue}

A few pycnotic nuclei were present in most follicles with three or more layers of granulosa cells. They seemed to be distributed at random among healthy cells as in atretic follicles in the normal ovary. The extent of pycnosis in actively growing follicles varied with treatment (Pl. 1, Fig. 6 and Pl. 2, Figs 7, 8 and 9). Gonsidering only those follicles with $25 \%$ or more labelled nuclei on Day 5 , $54 \%$ in LH-treated ovaries were assigned pycnosis scores greater than 2 , compared with $67 \%$ in the control ovaries and $15 \%$ in FSH-treated ovaries: FSH significantly reduced pycnosis $(P<0.01)$. The degree of pycnosis did not appear to vary with follicle growth rate. It varied with follicle size only in the presence of FSH, where $8 \%$ of the three-cell-layer follicles were given pycnosis scores exceeding 1 , compared with $21 \%$ in the four-cell-layer follicles and $61 \%$ in those with five or more layers. The difference between the latter two groups was significant $(P<0.01)$.

Although damaged tissue in the centre of the ovaries was much more restricted than in former experiments, pycnotic nuclei were present both in nonfollicular tissue and in a limited number of follicles with one to three layers of granulosa cells (PI. 2, Figs 11 and 12). In the latter, the nuclear material, especially of the innermost layer, appeared to have fragmented. A different type of small follicle degeneration occurred only in ovaries cultured without FSH (Pl. 2, Fig. 9). It was more marked where LH was present than in the controls and was much more evident on Day 5 than on Day 2. In this type, which was not confined to the centre of the ovary, many or all of the nuclei, irrespective of their position in the follicle, were small, compact and deeply stained, and were not infrequently also labelled. In the absence of FsH, fully enlarged oocytes surrounded by a single layer of unlabelled granulosa cells were also present (Pl. 2, Fig. 10), suggesting continued oocyte growth without accompanying follicle cell division (cf. Eshkol, Lunenfeld \& Peters, 1970).

Surrounding the central damaged zone was a region of healthier tissue in which no nuclei of any cell type were labelled (Pl. 1, Fig. 4). Here were remnants of follicles with one to three layers of granulosa cells in which the oocytes were degenerating, or had disappeared, without accompanying degeneration of all the granulosa cells (Pl. 2, Fig. 11). They were most numerous in ovaries 
cultured for 5 days with FsH. Both the central pycnotic zone and the unlabelled but healthier region extended furthest in FsH-treated ovaries.

Table 4 shows the estimated mean number of all follicles/ovary, other than primordials, for each treatment group. The numbers in the five size categories have been summed for each ovary, those of one- and two-cell-layer follicles being multiplied by five since they were only counted in every fifth section. The net loss between Day 2 and Day 5 was least in the controls and greatest in the FSH-treated ovaries but, owing to considerable variation within treatment groups, in no case was it significant. Already on Day 2, however, the LH-treated ovaries had significantly fewer such follicles than the controls.

TABLE 4

ESTIMATED NUMBER OF FOLLICLES PER MOUSE OVARY, OTHER THAN PRIMORDIALS

\begin{tabular}{l|c|c}
\hline & Day 2 & Day 5 \\
\hline LH & $753 \pm 17$ & $619 \pm 173$ \\
Control & $960 \pm 64$ & $884 \pm 52$ \\
FSH & $819 \pm 92$ & $598 \pm 116$ \\
\hline
\end{tabular}

Values expressed as Means \pm S.E.M.

\section{DISCUSSION}

The effects of FSH

Any change in the number of follicles of each size after a given period of culture is a consequence of recruitment from smaller categories, of promotion to larger ones and of degeneration. Two types of follicle degeneration were associated with or accentuated by the absence of FSH but the net losses of follicles suggested in Table 4 are likely to have resulted mainly from the conditions in vitro. The tendency for FSH-treated ovaries to lose more follicles and to have more extensive damaged and unlabelled zones probably reflected their more rapid growth and enhanced peripheral oxygen utilization. Simultaneously, their increased mass would have exacerbated the problem of gas diffusion. Nevertheless, net recruitment into the larger follicle-size categories was substantially greater in the presence of FSH than in either control or LH-treated ovaries and, even by Day 2, the labelling data indicated mitotic stimulation in follicles of all sizes, including primordials. In any case, the numbers of follicles within each category are, for the present purposes, of less concern than their rate of growth.

By Day 5, high proportions of one- and two-cell-layer follicles were growing only where FSH was present and FSH was also necessary for maintaining a high rate of growth in these smaller follicles. On the other hand, although the threeand four-cell-layer follicles in FsH-treated ovaries were growing as fast on Day 5 as on Day 2, the average growth rate in control and LH-treated ovaries was even greater. 
The effects of $L H$

In LH-treated and in control ovaries, primordial follicles were relatively poorly labelled on Day 2 and almost without label on Day 5 . The proportion of labelled one- and two-cell-layer follicles was high in both these groups on Day 2, due perhaps to the residual effect of mouse FSH, but it declined sharply by Day 5. The follicles tended to have more labelled nuclei in the presence of $\mathrm{LH}$, the three most rapidly growing one-cell-layer follicles having significantly more on Day 2. This slightly enhanced growth rate seems, however, inadequate to account for the significant deficit of one-cell-layer follicles on Day 2 which was reflected in the total follicle count. Possibly, LH inhibited recruitment from primordial follicles into the one-cell-layered category on Day 1 of culture. Such inhibition might account for the initial depression of DNA synthesis by LH reported previously (How, Chaplin \& Ryle, 1970).

In the absence of FSH, there was little recruitment into the three-cell-layer category by Day 2 and practically none into the four-cell-layer category (although, judging from comparable ovaries examined for other purposes, twoand three-cell-layer follicles would have been present at explantation). By Day 5 , however, not only were more three- and four-cell-layer follicles present but the rate of growth of some of them, even within control ovaries, was rapid. This acceleration was accentuated by LH and presumably corresponds to the delayed growth spurt observed previously (Ryle, 1971a). Had the cultures been maintained for 6 days, as in the earlier experiment, greater recruitment into still larger categories would presumably have occurred. The former results suggested that LH either recruited least effectively into the four-cell-layer category or accelerated the passage of follicles through this phase. The present results support the latter interpretation. Accelerated growth of follicles has been reported at about the same stage in vivo (Pedersen, 1970).

\section{Follicle growth in the absence of gonadotrophins}

The data obtained from the control ovaries showed that a small proportion of follicles is still able to grow, and even to grow rapidly, after 4 days' culture with no gonadotrophin. The distribution of follicle sizes and of labelling intensity, as well as the types and extent of pycnosis, resembled in most respects those of ovaries treated with LH. Fewer follicles grew, however, and they tended to grow more slowly. The special type of small follicle pycnosis was less marked but pycnotic nuclei in the larger follicles were somewhat more numerous. Control ovaries resembled FsH-treated ovaries in one respect: very few follicles had more than $75 \%$ labelled nuclei and these were exclusively in the category with five or more layers of granulosa cells.

\section{General discussion}

It was suggested previously that the delayed growth response to LH in vivo might be due to oestrogen which had to accumulate to a certain threshold concentration. The small tissue:medium ratio (about $1 \mathrm{mg}: 2 \mathrm{ml}$ ) and the immaturity of the ovaries cast doubt on this interpretation. Moreover, it seems unlikely that granulosa cells divide in response to two totally unrelated stimuli. The delay could represent the time required for LH molecules to break down 
into sub-units. Sheep FSH and LH appear to share a common sub-unit (Papkoff \& Ekblad, 1970) and the human FSH molecule appears to have more than one active site capable of stimulating the mouse ovary in vitro (Kennedy, Butt, Robinson \& Ryle, 1972). So it is conceivable that a sub-unit common to the two human gonadotrophins is able to stimulate follicle growth. However, the different 'spectra' of follicle sizes responding to FSH and to LH and the different vigour of the responses make this explanation unlikely.

Even if accelerated growth were not due to accumulated oestrogen, it could conceivably result from steroidogenesis. Steroid synthesis in the immature follicle, as in interstitial and luteal tissue, is probably stimulated by LH. Granulosa cells of immature follicles in the rat ovary lack a characteristic steroidogenic ultrastructure (Bjorkman, 1962) such as occurs in the theca interna (Christensen \& Gillim, 1969). The theca interna of the normal mouse follicle begins to differentiate at about the two-cell-layer stage (Brambell, 1928), i.e. just before the stage when, in this experiment, the follicles became fully responsive to LH. Luteinizing hormone appeared to stimulate thecal-cell mitosis while FSH possibly tended to depress it. Thecal cells may mature slowly, perhaps dividing several times, before they become capable of synthesizing steroids and LH may accelerate this maturation. Adrenocorticotrophic hormone induces morphoogical and biochemical maturation in cultured cells from the adrenal cortex of the fetal rat, a process which takes 3 days and which confers on the cells the capacity for acute steroidogenic responses to the same pituitary hormone (Milner, 1971).

Falck (1959) showed that both theca and granulosa cells were necessary for oestrogen synthesis. The contribution of the granulosa-cell layer has not been identified but could be a substance involved both in steroidogenesis and in the control of granulosa-cell mitosis. If the substance was a mitotic inhibitor, depletion resulting from thecal steroid synthesis would permit more rapid granulosa-cell division, the rates of the two processes being related. Premature maturation and enhanced steroidogenesis in the theca, due to pure LH, would result in intense mitotic activity in unusually small follicles. It may be assumed that FSH would deplete the inhibitor less drastically, and by other means, in follicles of all sizes. With FSH, but no LH, follicle growth would be somewhat accelerated but the theca cells would mature at the control rate. Consequently, intense mitotic activity would be confined to larger follicles. Given the stated assumptions, the consequences correspond to the observed results.

The association of premature oocyte spindles with rapidly growing follicles suggests the possibility of meiotic, as well as mitotic, inhibition. The maturation of oocytes in various species following removal from the unripe follicle (Edwards, 1965) also suggests that development is arrested within the environment provided by the granulosa cells. In intact animals, the normal preovulatory surge of $\mathbf{L H}$ may induce rapid steroidogenesis in batches of follicles insufficiently matured under the control of FSH, so releasing them from meiotic inhibition before normal ovulation is possible. Such premature release could account for the 'waves' of atretic follicles observed in the cycling animal. 


\section{ACKNOWLEDGMENTS}

I wish to thank Dr A. G. Crooke and Dr W. R. Butt for their continued encouragement, Miss M. Wardill for technical assistance, Mr P. V. Bertrand for statistical advice and the Ford Foundation for financial support.

\section{REFERENCES}

Bjorkman, N. (1962) A study of the ultrastructure of the granulosa cells of the rat ovary. Acta anat. 51, 125.

Brambell, F. W. R. (1928) The development and morphology of the gonads of the mouse. Part III. The growth of the follicles. Proc. R. Soc. B, 103, 258.

ButT, W. R., LyNCH, S. S. \& KENNEdy, J. F. (1972) Studies on the preparation of human pituitary follicle stimulating hormone. IInd Int. Symp. Protein and Polypeptide Hormones, Liège, 1971. Vol. 2. Eds. M. Margoulies and F. G. Greenwood. Excerpta Medica, Amsterdam. (In press).

Christensen, A. K. \& Gillim, S. W. (1969) The correlation of fine structure and function in steroid-secreting cells, with emphasis on those of the gonads. In: The Gonads, p. 415. Ed. K. W. McKerns. North Holland Publ. Co., Amsterdam.

EDwards, R. G. (1965) Maturation in vitro of mouse, sheep, cow, pig, rhesus monkey and human ovarian oocytes. Nature, Lond. 208, 349.

Eshkol, A., Lunenfeld, B. \& Peters, H. (1970) Ovarian development in infantile mice; dependence on gonadotrophic hormones. In: Gonadotrophins and Ovarian Development, p. 249. Eds. W. R. Butt. A. C. Crooke and M. Ryle. Livingstone, Edinburgh.

FALCK, B. (1959) Site of production of oestrogen in the ovary of the rat. Nature, Lond. 184, 1082.

How, M. J., Chaplin, M. F. \& Ryle, M. (1970) The distribution of $\left[{ }^{14} \mathrm{C}\right]$ thymidine in mouse ovaries cultured in vitro with and without gonadotrophic hormones. Biochim. biophys. Acta, 213, 226.

Kennedy, J. F., ButT, W. R., RoBinson, W. \& Ryle, M. (1972) The retention of biological activity by fragments of follicle stimulating hormone after fractionation. IInd Int. Symp. Protein and Polypeptide Hormones, Liège, 1971. Vol. 2. Eds. M. Margoulies and F. G. Greenwood. Excerpta Medica, Amsterdam. (In press).

Milner, A. J. (1971) ACTH and the differentiation of rat adrenal cortical cells grown in primary tissue culture. Endocrinology, 88, 66.

PAPkoff, H. \& Ekblad, M. (1970) Ovine follicle stimulating hormone: preparation and characterization of subunits. Biochem. biophys. Res. Commun. 40, 614 .

Pedersen, T. (1970) Determination of follicle growth rate in the ovary of the immature mouse. 7 . Reprod. Fert. 21, 81.

RyLE, M. (1971a) The time factor in responses to pituitary gonadotrophins by mouse ovaries in vitro. 7. Reprod. Fert. 25, 61 .

RyLE, M. (1971b) The activity of human follicle-stimulating hormone preparations as measured by a response in vitro. 7 . Endocr. 51, 97. 